\title{
Production of interspecific hybrids between commercial cultivars of the eggplant (Solanum melongena L.) and its wild relative $S$. torvum
}

\author{
J. Kumchai ${ }^{1}$, Y.-C. Wei ${ }^{2}$, C.-Y. Lee ${ }^{2}$, F.-C. Chen ${ }^{2}$ and S.-W. Chin ${ }^{2}$ \\ ${ }^{1}$ Department of Tropical Agriculture and International Cooperation, \\ National Pingtung University of Science and Technology, Pingtung, Taiwan \\ ${ }^{2}$ Department of Plant Industry, \\ National Pingtung University of Science and Technology, Pingtung, Taiwan \\ Corresponding authors: S.-W. Chin / F.-C. Chen \\ E-mail: swchin@mail.npust.edu.tw / fchen@mail.npust.edu.tw
}

Genet. Mol. Res. 12 (1): 755-764 (2013)

Received June 5, 2012

Accepted November 14, 2012

Published March 13, 2013

DOI http://dx.doi.org/10.4238/2013.March.13.4

\begin{abstract}
Interspecific hybrids between cultivars of eggplant (Solanum melongena L.) and its wild relative S. torvum, which has disease resistance and desirable traits for crop improvement, were obtained by cross-hybridization and embryo rescue. Twenty-one hybrid progenies were obtained and examined based on morphological traits, RAPD and ISSR markers. Five of them were confirmed to be true interspecific hybrids. Eighteen and 14 bands from 7 RAPD and 14 ISSR primers, respectively, were polymorphic and present in all five hybrid seedlings and their parents. The morphological characteristics of leaf margin, inflorescence type and spine positions of the five seedlings were intermediate to the parents. These interspecific hybrids had low pollen viability, probably due to abnormal meiosis.
\end{abstract}

Key words: Interspecific hybrids; Morphological trait; RAPD; ISSR; Solanum melongena; Solanum torvum 


\section{INTRODUCTION}

Eggplant (Solanum melongena L.) is an economically important vegetable crop across many countries in Asia and Africa (Collonnier et al., 2003). There is wide genetic diversity within the cultivated species as well as within the wild species. Solanum torvum is closely related to eggplant (S. melongena L.), a native of India. It has desirable traits such as disease resistance, which may be transferred by introgression into the eggplant genome (Singh et al., 2006; Baysal et al., 2010). Several studies have shown that $S$. torvum has high levels of resistance towards pests, nematodes and pathogens (Collonnier et al., 2003; Clain et al., 2004; Gousset et al., 2005). It has been used as a rootstock for the grafting of susceptible tomato and eggplant varieties (Peregrine and Ahmad, 1982; Singh and Gopalakrishnan, 1997). Moreover, interspecific crosses between plant species are an ideal way for introducing desirable genetic traits in breeding programs. They may be able to solve problems such as disease resistance and even create new hybrid characters. In a few cases, interspecific crosses by conventional breeding have successfully created novel cultivars, such as Hakuran (cabbage x Chinese cabbage) of Brassica, hot pepper and potato of Solanum (Briggs and Knowles, 1967; Gleddie et al., 1986).

Studies on grafting between $S$. melongena and $S$. incanum, $S$. aethiopicum and $S$. habrochaites germplasm, as well as intraspecific and interspecific eggplant hybrids, have shown promising results for developing new rootstocks for eggplant production (Gisbert et al., 2011). Another technique known as somatic hybridization has also been attempted for transferring useful genes from wild species to cultivated plants through protoplast fusion (Jarl et al., 1999; Kashyap et al., 2002). However, the lack of reports on subsequent integration of interspecific hybrids or somatic hybrids in eggplant breeding programs suggests some remaining obstacles for these hybrids. Furthermore, the identification of interspecific hybrids relies on both morphological traits and molecular markers. If the hybrid is morphologically similar to one of its parents, molecular markers such as inter-simple sequence repeats (ISSR) and random amplified polymorphic DNA (RAPD) are necessary to help in progeny identification (Ilbi, 2003; Yonemoto et al., 2006; Isshiki et al., 2008; Biswas et al., 2009; Demir et al., 2010). RAPD and ISSR markers have revealed polymorphic DNA bands that differ between genotypes of strawberry. These markers have identified genetic distance between genotypes and have allowed the estimation of how closely related they are. Moreover, both markers have been successfully used to analyze tomato cultivars and individual species (Martins et al., 2003; Tikunov et al., 2003).

The aims of the present study were to develop interspecific hybrids between commercial cultivars of eggplant $S$. melongena and $S$. torvum, confirming their progeny by both phenotypic traits and polymerase chain reaction (PCR)-based molecular markers to identify true hybrid lines. To make better use of the hybrids in advanced breeding programs, pollen viability was evaluated in the parental lines and their progeny for further introgression.

\section{MATERIAL AND METHODS}

\section{Plant material}

S. torvum [T (Figure 1)] was used as the male parent, and 4 cultivars of $S$. melongena [Pai Chieh (W10); Purple Bride 1 (P1); Purple Bride 23 (P23), and Purple Bride 24 (P24)] were used as the female parents. A total of 21 hybrid seedlings (Table 1) were obtained through embryo rescue in vitro (Wei, 2010) and used in this study. 


\begin{tabular}{|c|c|c|}
\hline Accession & Code & Sample No \\
\hline \multicolumn{3}{|l|}{ Parental lines } \\
\hline Solanum torvum & $\mathrm{T}$ & 1 \\
\hline \multirow{4}{*}{ Solanum melongena } & P1 & 2 \\
\hline & P23 & 3 \\
\hline & W10 & 4 \\
\hline & P24 & 5 \\
\hline \multicolumn{3}{|l|}{ Hybrids } \\
\hline P1 x T & & 6 \\
\hline $\mathrm{P} 23 \times \mathrm{T}$ & & $7-16$ \\
\hline P24 x T1 & & $17-18$ \\
\hline $\mathrm{W} 10 \times \mathrm{T} 1$ & & $19-26$ \\
\hline
\end{tabular}

For sample number identification, see Figure 3.

\section{Embryo rescue}

On the day before flowering, male flowers were collected to obtain pollens. During mature flower bud stage two to three days before opening, emasculation was performed to prevent potential pollen contamination of female parents. Pollination was conducted in a greenhouse and the flowers bagged after pollination. Seeds or underdeveloped ovules were harvested from mature fruits when their skin turned a yellow or brown color depending on the cultivar. The seeds were cleaned and sterilized using $70 \%$ ethanol for 2 min and then $0.6 \%$ sodium hypochlorite for $5 \mathrm{~min}$, rinsed three times in sterile water, and transferred to Murashige and Skoog medium (MS) (Murashige and Skoog, 1962) supplemented with $30 \mathrm{~g} / \mathrm{L}$ sucrose and $7 \mathrm{~g} / \mathrm{L}$ Sigma agar. In vitro cultures were kept at $25^{\circ} \pm 2^{\circ} \mathrm{C}$ with a 16 -h photoperiod with a light intensity of $35-40 \mu \mathrm{mol} \cdot \mathrm{m}^{-2} \cdot \mathrm{s}^{-1}$. After seeds were germinated, shoot cuttings were subcultured in the same MS medium 2 to 3 times for adventitious root formation and then transplanted to a peat moss substrate by acclimation in a greenhouse.

\section{RAPD and ISSR analyses}

Genomic DNA was extracted from $0.2 \mathrm{~g}$ young leaves according to a modified CTAB method (Winnepenninckx et al., 1993). Briefly, leaf samples were ground with a mortar and pestle in liquid nitrogen. The homogenate was dissolved in CTAB buffer, and the mixture heated to $55^{\circ} \mathrm{C}$ for $5 \mathrm{~min}$. An isoamyl alcohol:chloroform (24:1) solution was then added to the resulting homogenates, mixed thoroughly and then centrifuged at 13,000 rpm (Centrifuge $5415 \mathrm{R}$ ) for $5 \mathrm{~min}$. DNA was precipitated from the supernatant by adding an equal volume of ice-cold isopropanol. The tube was put into liquid nitrogen for $2 \mathrm{~min}$. DNA was then pelleted by centrifuging at $13,000 \mathrm{rpm}$ for $25 \mathrm{~min}$. The pellets were then washed with ice-cold $70 \%$ ethanol and spun for $5 \mathrm{~min}$. The pellets were then washed with ice-cold $90 \%$ ethanol. The DNA pellet was air-dried and resuspended in $35 \mu \mathrm{L}$ sterile water. The quality and concentration of isolated DNA were determined with a spectrophotometer (Hitachi U-2900 UV-Vis Double Beam System). To remove any RNA in the preparation, $5 \mu \mathrm{L} 40 \mathrm{U} / \mu \mathrm{L}$ RNase was added and the mixture incubated at $37^{\circ} \mathrm{C}$ for $1 \mathrm{~h}$.

RAPD and ISSR analyses were performed in a $15-\mu \mathrm{L}$ volume of reaction mixture by 
using the TaKaRa LA PCR kit ver. 2.1, which contained 10X PCR buffer $\left(25 \mathrm{mM} \mathrm{Mg}^{2+}\right), 5$ $\mathrm{U}$ Taq DNA polymerase, $2.5 \mathrm{mM}$ dNTP mixture, $2.5 \mu \mathrm{M}$ random decamer primer and $50 \mathrm{ng}$ total genomic DNA. Thirty RAPD decamer primers from the Operon kit (Operon Technology, OPT 1-20 and OPF 1-10) and 33 ISSR primers of the UBC primer set were used. The other ISSR primer sets were screened according to Raina et al. (2001), Bornet et al. (2002), Mariana et al. (2006), and Biswas et al. (2009). The amplification of RAPD was performed with initial denaturation at $94^{\circ} \mathrm{C}$ for $2 \mathrm{~min}, 39$ cycles of denaturating at $94^{\circ} \mathrm{C}$ for $1 \mathrm{~min}$, annealing at $37^{\circ} \mathrm{C}$ for $1 \mathrm{~min}$ and extension at $72^{\circ} \mathrm{C}$ for $2 \mathrm{~min}$, and a final extension at $72^{\circ} \mathrm{C}$ for $12 \mathrm{~min}$ in a thermocycler (Applied Biosystem 9700). For ISSR amplification, the thermocyler was programmed with pre-denaturation at $94^{\circ} \mathrm{C}$ for $3 \mathrm{~min}$, one cycle, then 45 cycles of denaturation at $94^{\circ} \mathrm{C}$ for $30 \mathrm{~s}$, annealing at $55-59^{\circ} \mathrm{C}$ for $45 \mathrm{~s}$ and extension at $72^{\circ} \mathrm{C}$ for $2 \mathrm{~min}$, and a final extension at $72^{\circ} \mathrm{C}$ for $5 \mathrm{~min}$. The product was resolved on a $2 \%$ agarose gel in TAE buffer at $80 \mathrm{~V}$ and stained with ethidium bromide. The stained gels were visualized under UV light and image captured by Gel Doc 2000 Gel Documentation System.

\section{Pollen viability}

Evaluation of pollen viability followed the method reported by Alexander (1969). Two to four drops of the stain solution were applied on shed pollen on a glass slide, which were gently mixed and then coverslipped. Pollen staining was observed under a light microscope (Olympus CX40) after 15 min to ensure the stain had been completely absorbed by the pollen grains. Putative interspecific hybrids and parental lines were collected from 10 flowers per accession. A total of 1000 pollen were scored by percentage for each accession ( 100 pollen cells per anther and replicated for each flower). Alexander's stain reveals blue-green color in aborted pollen grains while magenta-red in viable pollen grains.

\section{RESULTS}

\section{Obtaining interspecific hybrids through embryo rescue}

Preliminary study on sowing the seeds from reciprocal cross-pollinations between $S$. torvum and S. melongena directly in a potting mix failed to obtain any interspecific hybrid. Therefore, we examined the seeds or ovules harvested from mature fruits under a dissecting microscope. We observed many underdeveloped ovules (rudimentary seeds) in the interspecific crosses, which might have been the reason for no seed germination after direct sowing in potting substrate. The embryo rescue strategy was then adopted to raise potential interspecific progeny from the interspecific crosses after pollination and fruit maturation, with selfed female lines for comparison. More than 50\% seeds germinated in selfed female lines, but at a very low germination rate in interspecific crosses (Table 2), probably due to the underdevelopment of the rudimentary embryos in interspecific cross-combinations of PxT and WxT. The in vitro germinated hybrid seedlings showed abnormal development or weak growth. They were either subcultured in fresh germination medium for further growth, or single node cuttings were inserted into the same MS medium for shoot growth and adventitious root formation. Subsequently, a total of 21 seedlings were regenerated after in vitro rescue, then transplanted in pots and used to characterize their hybrid nature. 
Table 2. Number of seeds and germination rate from female lines and interspecific crossings.

\begin{tabular}{|c|c|c|c|c|}
\hline \multirow[t]{2}{*}{ Accession } & \multicolumn{2}{|c|}{ Seed No. (\%) } & \multicolumn{2}{|c|}{$\%$ Seed germination } \\
\hline & Rudimentary & Normal & Rudimentary & Normal \\
\hline Solanum melongena $(\mathrm{P})$ & $173.0(18.1)$ & $781.0(81.9)$ & ND & 66.7 \\
\hline Solanum melongena $(\mathrm{W})$ & $262.0(15.0)$ & $1489.0(85.0)$ & ND & 71.4 \\
\hline PxT & $194.9(70.1)$ & $83.3(29.9)$ & 0.3 & 0.4 \\
\hline WxT & $391.7(87.2)$ & $57.7(12.8)$ & 0.0 & 7.2 \\
\hline
\end{tabular}

$\mathrm{ND}=$ not determined

\section{Morphological traits and pollen viability in hybrid progeny}

The 21 putative interspecific hybrid progenies were derived from the following parental combinations: (P1xT) strain A-2, (P24xT) strain B-1, (W10xT) strain G-2, (W10xT) strain $\mathrm{C}-1$, and (W10xT) strain D-1. Among them, the dentate leaf margin of mature leaves in 5 seedlings was similar to that of the male parent S. torvum. The leaf shape of these hybrids was similar compared to the female parents, with deep lobate and the positions of the vein overlapping between two sides (Figure 1A-D). Moreover, the hybrid plants, like their male parents, were the shrub type and branched, with thorns on the leaves and stems (data not shown).

The pollen viability of parental lines, S. melongena, Purple Bride (P), Pai Chieh (W), and $S$. torvum (T), was almost $100 \%$ as revealed by dark staining (Table 3 ). Their pollen were round in shape and of uniform, normal size (Figure 2A-C). The pollen viability of the hybrid progeny (P1xT) strain A-2, (P24xT) strain B-1, (W10xT) strain C-1, (W10xT) strain D-1, and (W10xT) strain G-2 varied between normal, dark stain (0 to 9.8\%) and abnormal and light or no stain, which indicated rudimentary (4.5 to $96.2 \%)$ and empty pollen (1.3 to $95.5 \%)$, respectively (Table 3). Viable pollen counts of the hybrid progeny were low, and (W10xT) strain C-1 showed almost no viable pollen (Figure 2D-F).
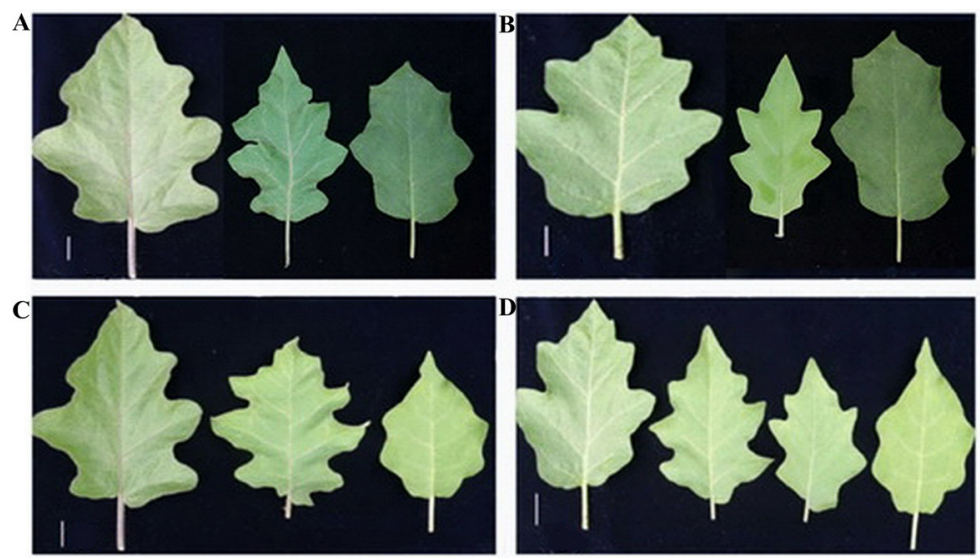

Figure 1. Leaf morphology of interspecific hybrids and their parental lines. From left to right: A. A female line (P1), interspecific hybrid (P1xT) strain A-2, male line Solanum torvum (T). B. A female line (P24), interspecific hybrid (P24xT) strain B-1, male line $S$. torvum (T). C. A female line (W10), interspecific hybrid (W10xT) strain G-2, male line S. torvum (T). D. A female line (W10), interspecific hybrid (W10xT) strain C-1, interspecific hybrid (W10xT) strain D-1, male line S. torvum (T). Bar $=2.5 \mathrm{~cm}$. 
A

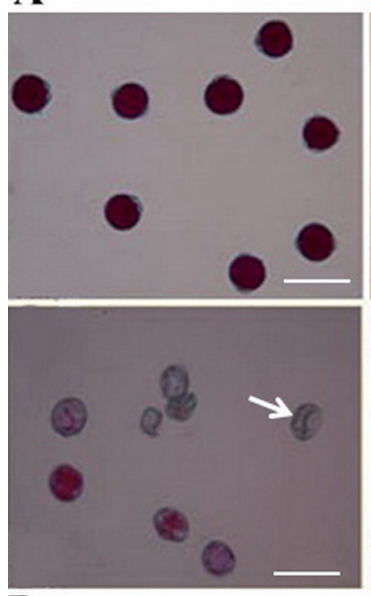

D
B

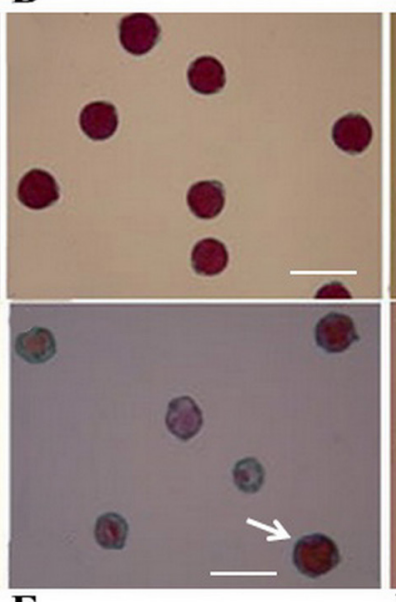

$\mathbf{E}$
C

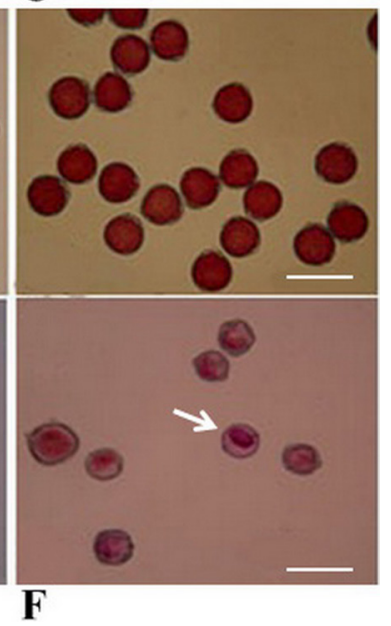

Figure 2. Pollen viability of parental lines: A. Purple Bride. B. Pai Chieh. C. Solanum torvum. D. Interspecific hybrid (P1xT) strain A-2. E. Interspecific hybrid (P24xT) strain B-1. F. Interspecific hybrid (W10xT) strain D-1. The arrows in D, E, and F represent empty, normal, and rudimentary, respectively. Bar $=0.05 \mathrm{~mm}$.

Table 3. Pollen viability of eggplant parents and progenies.

\begin{tabular}{lrrr}
\hline Accession & & \multicolumn{2}{c}{ Viability (\%) } \\
\cline { 2 - 4 } & \multicolumn{1}{c}{ Normal } & Rudimentary & Empty \\
\hline Solanum melongena $(\mathrm{P})$ & $98.1 \pm 1.4$ & $0.0 \pm 0.0$ & $1.9 \pm 1.4$ \\
Solanum melongena $(\mathrm{W})$ & $99.6 \pm 0.5$ & $0.0 \pm 0.0$ & $0.4 \pm 0.5$ \\
Solanum torvum $(\mathrm{T})$ & $98.3 \pm 2.7$ & $0.0 \pm 0.0$ & $1.7 \pm 2.7$ \\
(P1xT) A-2 & $3.8 \pm 4.1$ & $55.7 \pm 6.7$ & $40.5 \pm 3.8$ \\
(P24xT) B-1 & $9.8 \pm 7.3$ & $57.2 \pm 8.4$ & $33.0 \pm 7.1$ \\
(W10xT) C-1 & $0.0 \pm 0.0$ & $4.5 \pm 2.0$ & $95.5 \pm 2.0$ \\
(W10xT) D-1 & $2.6 \pm 1.6$ & $96.2 \pm 2.4$ & $1.3 \pm 1.3$ \\
(W10xT) G-2 & $0.0 \pm 0.0$ & $53.1 \pm 6.8$ & $46.4 \pm 6.1$ \\
\hline
\end{tabular}

${ }^{\mathrm{a}}$ Abnormal pollens include rudimentary and empty pollens.

\section{Identification of interspecific hybrids by RAPD and ISSR markers}

Of the 30 RAPD primers used, a total of 81 clear and reproducible bands were generated by 7 primers. The number of bands for each primer varied from 8 (OPF-09) to 15 (OPT-01) with an average of 12 bands per primer. Of the bands generated, $63(77.78 \%)$ were present in all parental and hybrid lines tested. The other bands $(22.22 \%)$ were polymorphic among samples. The primer that resulted in the most polymorphic RAPD markers was OPF-3 (Table 4). OPF-12 and -16 primers produced polymorphic bands combined from both parents in seedling samples 6 (P1xT A-2), 18 (P24xT B-1), 22 (W10xT C-1), 23 (W10xT D-1), and 26 (W10xT G-2), suggesting that these 5 plants were true interspecific hybrids (Figure 3A and B). Fourteen of 33 ISSR primers generated a total of 157 clear and reproducible bands, 
of which $16(10.19 \%)$ were polymorphic (Table 5). All primers generated low polymorphic patterns, and each individual showed different amplification patterns (Table 6). The UBC866 and ISSR-N1.4 markers (Figure 3C and D) also revealed the same interspecific hybrids as with RAPD markers.

Table 4. List of the RAPD primers producing amplified pattern and their sequences for cultivar identification of eggplant.

\begin{tabular}{llcr}
\hline Primer & DNA sequence (5'-3') & Total bands & Polymorphic bands \\
\hline OPF-02 & GAGGATCCCT & 10 & 3 \\
OPF-03 & CCTGATCACC & 12 & 4 \\
OPF-04 & GGTGATCAGG & 14 & 3 \\
OPF-09 & CCAAGCTTCC & 8 & 1 \\
OPF-12 & ACGGTACCAG & 11 & 1 \\
OPF-16 & GGAGTACTGG & 11 & 3 \\
OPT-01 & GGGCCACTCA & 15 & 2 \\
Total & & 81 & 17 \\
\hline
\end{tabular}

A

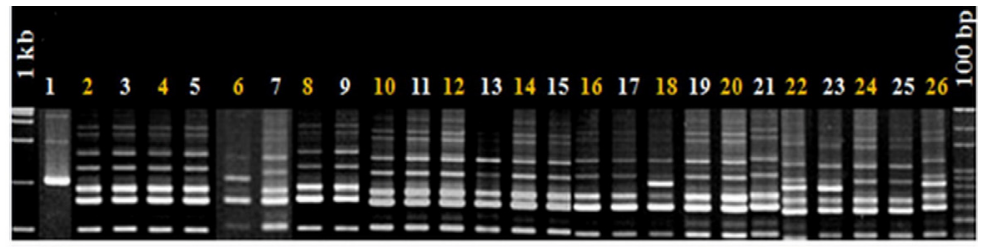

B

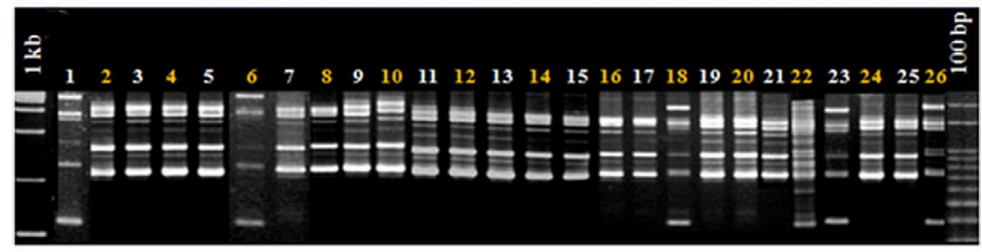

C

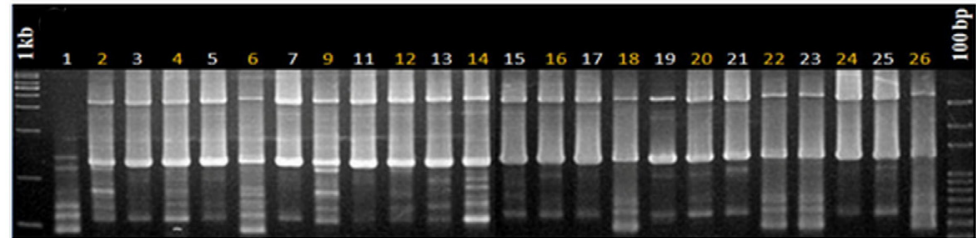

D

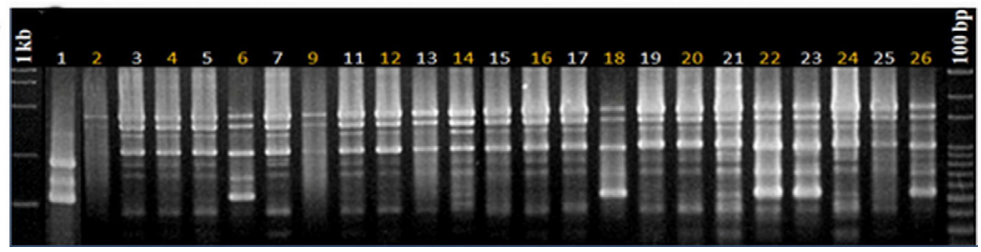

Figure 3. RAPD and ISSR markers generated by primers OPF-12 (A), OPF-16 (B), UBC866 (C), and ISSR-N1.4 (D) of parental lines and hybrid seedlings. Lanes 1 to 26 = T; P1; P23; W10; P24; (P1xT) A-2; (P23xT) B-4; (P23xT) A-1; (P23xT) H-4; (P23xT) J-4; (P23xT) L-2; (P23xT) N-1; (P23xT) P-2; (P23xT) R-2; (P23xT) S-1; (P23xT) U-1; (P24xT) A-2; (P24xT) B-1; (W10xT) A-4; (W10xT) A-4; (W10xT) B-4; (W10xT) C-1; (W10xT) D-1; (W10xT) E-4; (W10xT) E-2; (W10xT) G-2, respectively. The true interspecific hybrids, are numbers 6 (P1xT A-2), 18 (P24xT B-1), 22 (W10xT C-1), 23 (W10xT D-1), and 26 (W10xT G-2). 
Table 5. List of the ISSR primers producing amplified pattern and their sequences for cultivar identification of eggplant.

\begin{tabular}{|c|c|c|c|}
\hline Primer & DNA sequence & Total bands & Polymorphic bands \\
\hline UBC808 & $(\mathrm{AG})_{7} \mathrm{C}$ & 13 & 1 \\
\hline UBC866 & $\mathrm{CT}(\mathrm{CCT})_{5} \mathrm{C}$ & 11 & 1 \\
\hline ISSR-E1.1 & $\mathrm{CT}(\mathrm{CCT})_{5} \mathrm{C}$ & 16 & 2 \\
\hline ISSR-E1.2 & $\mathrm{CC}(\mathrm{ATG})_{5}$ & 10 & 1 \\
\hline ISSR-E1.3 & $\mathrm{CCA}(\mathrm{TG})_{7}^{3} \mathrm{~T}$ & 11 & 1 \\
\hline ISSR-E1.4 & $\mathrm{GCA}(\mathrm{AC})_{7}$ & 9 & 2 \\
\hline ISSR-P2.1 & $\mathrm{GAG}(\mathrm{CAA})_{5}$ & 8 & 1 \\
\hline ISSR-P2.3 & $\mathrm{CT}(\mathrm{GA})_{8}$ & 13 & 1 \\
\hline ISSR-T1.1 & $\mathrm{A}(\mathrm{GA})_{7} \mathrm{GT}$ & 9 & 1 \\
\hline ISSR-N1.4 & CCCGGATCC $(\mathrm{CA})_{9}$ & 10 & 1 \\
\hline ISSR-C1.4 & $\mathrm{CGCAAC}_{(\mathrm{GA})_{8}}$ & 11 & 1 \\
\hline ISSR-C1.7 & $\operatorname{CGTAC}(\mathrm{GT})_{8} 8$ & 11 & 1 \\
\hline ISSR-C1.8 & $\mathrm{CGAGCG}(\mathrm{CCG})_{2} \mathrm{CC}$ & 8 & 1 \\
\hline ISSR-C1.9 & AAATTCA $(\mathrm{GCA})_{3} \mathrm{G}$ & 12 & 1 \\
\hline Total & & 152 & 16 \\
\hline
\end{tabular}

Table 6. Ten RAPD and two ISSR markers identified in interspecific hybrids.

\begin{tabular}{|c|c|c|c|c|c|}
\hline Marker & (P1xT) & (P24xT) & (W10xT) & (W10xT) & (W10xT) \\
\hline $\mathrm{OPF} 2_{800}$ & + & - & - & - & - \\
\hline $\mathrm{OPF}_{950}$ & + & - & - & - & - \\
\hline $\mathrm{OPF}_{1400}$ & + & - & - & - & - \\
\hline $\mathrm{OPF}_{800}$ & - & + & + & + & - \\
\hline $\mathrm{OPF}_{900}{ }^{000}$ & + & + & - & - & - \\
\hline OPF $12_{750}$ & - & + & + & + & + \\
\hline OPF $16_{750}^{150}$ & + & - & - & - & - \\
\hline OPF $16_{1500}^{150}$ & + & + & - & + & + \\
\hline $\mathrm{OPT}_{1}{ }_{700}^{1500}$ & + & - & - & + & - \\
\hline OPT2 ${ }_{1050}$ & + & + & + & - & + \\
\hline ISSR-E1.1 $1_{500}$ & - & + & - & + & + \\
\hline ISSR-E1.4 $4_{1050}$ & + & - & + & + & - \\
\hline
\end{tabular}

$(+)=$ presence; $(-)=$ absence.

\section{DISCUSSION}

The hybrid seeds sown in conventional potting mix did not show any sign of germination, which is in contrast to the report by Hao et al. (2009) that seedlings were able to germinate in the potting mix. The failure of our hybrid seeds to germinate normally in potting mix was probably due to the different genetic background of parental lines despite the same species combination. This study revealed that through cross-hybridization between $S$. melongena and $S$. torvum, a total of 21 seedlings were recovered through embryo rescue, of which 5 were identified to be true interspecific hybrids, both by morphological traits and molecular markers. Embryo culture technique has been successfully used to obtain interspecific hybrids in crops such as Trifolium and tomato. This method offers the chance to rescue plantlets from underdeveloped embryos by culturing on a suitably nutritional medium (Evans, 1962; Katznelson, 1971; Segeren et al., 1993; Kaushal et al., 2005).

RAPD and ISSR markers have been successfully used for interspecific hybrid identification, parental line selection for hybridization, cultivar identification, variety tests, organiz- 
ing germplasm for conservation, and predicting favorable heterotic combinations (Martins et al., 2003; Tikunov et al., 2003; Bharathiraja et al., 2008; Cvikic et al., 2009). In this study, we were able to identify interspecific hybrids by using only 7 RAPD and 14 ISSR markers after PCR screening of 30 RAPD and 33 ISSR primers (Table 6), which only took a few working days.

The poor pollen viability observed in interspecific hybrid pollen (Figure 2; Table 3) was probably due to meiotic abnormality in chromosome behaviors, as has been reported in Capsicum spp, pepino (S. muricatum Ait.) and S. melongena x S. integrifolium (Grigg et al., 1988; Ali et al., 1992; Falusi and Morakinyo, 1994). Translocations and chromosome pairing could contribute to low hybrid fertility (Kumar et al., 1987; Pickersgill, 1997; Monteiro et al., 2011). This problem can be resolved by chemical treatment with colchicine, which has been successfully applied to double the chromosome number (Anderson et al., 1991). Alternatively, harvesting pollen in different seasons, such as spring time (Kowalczyk et al., 2008), may result in pollen with higher viability to improve pollination and promote advanced generation in subsequent breeding.

\section{ACKNOWLEDGMENTS}

Research supported by the Agriculture and Food Agency, Council of Agriculture, Executive Yuan, Taiwan [Grants \#100AS-4.2.2-FD-Z2(1), \#99AS-4.2.2-FD-Z2(2), \#98AS4.2.2-FD-Z2(23), and \#97AS-4.2.2-FD-Z2(14)].

\section{REFERENCES}

Alexander MP (1969). Differential staining of aborted and nonaborted pollen. Stain Technol. 44: 117-122.

Ali M, Okubo H and Fujieda K (1992). Production and characterization of Solanum amphidiploids and their resistance to bacterial wilt. Sci. Hort. 49: 181-196.

Anderson JA, Mousset-Déclas G, Williams EG and Taylor NL (1991). An in vitro chromosome doubling method for clovers (Trifolium spp.). Genome 34: 1-5.

Baysal O, Siragusa M, Gümrükcü E, Zengin S, et al. (2010). Molecular characterization of Fusarium oxysporum $\mathrm{f}$. melongenae by ISSR and RAPD markers on eggplant. Biochem. Genet. 48: 524-537.

Bharathiraja B, Jayamuthunagai J, Haritharini V and Ramya KR (2008). An approach to suggest the possibilities of interspecific hybridization using RAPD analysis of some commercial fruits and vegetables for improving the genetic characteristics. Adv. Biotechnol. 18: 21.

Biswas S, Akhond AY, Amin A, Khatun M, et al. (2009). Genetic relationship among ten promising eggplant varieties using RAPD markers. Plant Tissue Cult. Biotechnol. 19: 119-126.

Bornet B, Goraguer F, Joly G and Branchard M (2002). Genetic diversity in European and Argentinian cultivated potatoes (Solanum tuberosum subsp. tuberosum) detected by inter-simple sequence repeats (ISSRs). Genome 45: 481-484.

Briggs FN and Knowles PF (1967). Introduction to Plant Breeding. In: Interspecific Hybridization (Anderson E, ed.). Reinhold Publishing, New York, 317-333.

Clain C, Silva DD, Focka I, Vaniet S, et al. (2004). RAPD genetic homogeneity and high levels of bacterial wilt tolerance in Solanum torvum Sw. (Solanaceae) accessions from Reunion Island. Plant Sci. 166: 1533-1540.

Collonnier C, Fock I, Daunay MI, Servaes A, et al. (2003). Somatic hybrids between Solanum melongena and S. sisymbrifolium, as a useful source of resistance against bacterial and fungal wilts. Plant Sci. 164: 849-861.

Cvikic D, Pavlovic N, Zdravkovic M and Prodanovic S (2009). RAPD marker related to elongated fruit shape in pepper (Capsicum annum L.). Acta Hort. 830: 97-100.

Demir K, Bakir M, Sarikamis G and Acunalp S (2010). Genetic diversity of eggplant (Solanum melongena) germplasm from Turkey assessed by SSR and RAPD markers. Genet. Mol. Res. 9: 1568-1576.

Evans AM (1962). Species hybridization in Trifolium. II. Investigating the prefertilization barriers to compatibility. Euphytica 11: 256-262. 
Falusi OA and Morakinyo JA (1994). Intra-and interspecific hybridization in the genus Capsicum. Afr. Crop. Sci. Soc. 2: 169-171.

Gisbert C, Prohens J and Nuez F (2011). Performance of eggplant grafted onto cultivated, wild, and hybrid materials of eggplant and tomato. Int. J. Plant Prod. 5: 367-380.

Gleddie S, Keller KW and Setterfield G (1986). Production and characterization of somatic hybrids between Solanum melongena L. and S. sisymbrifolium Lam. Theor. Appl. Genet. 71: 613-621.

Gousset C, Collonnier C, Mulya K, Mariska I, et al. (2005). Solanum torvum, as a useful source of resistance against bacterial and fungal diseases for improvement of eggplant (S. melongena L.). Plant Sci. 168: 319-327.

Grigg FDW, Smith PR, Stenersen MA and Murray BG (1988). Variablepollen fertilityand abnormal chromosome behaviour in the pepino (Solanum muricatumAit., Solanaceae). Sci. Hort. 35: 259-268.

Hao CB, Jun LJ, Yong W, Qing LY, et al. (2009). Inter-specific hybridization between Solanum melongena and Solanum torvum. Acta Hort. Sin. 36: 209-214.

Ilbi H (2003). RAPD markers assisted varietal identification and genetic purity test in pepper, Capsicum annuum. Sci. Hort. 97: 211-218.

Isshiki S, Iwata N and Khan MR (2008). ISSR variations in eggplant (Solanum melongena L.) and related Solanum species. Sci. Hort. 117: 186-190.

Jarl CI, Rietveld EM and Haas JM (1999). Transfer of fungal tolerance through interspecific somatic hybridisation between Solanum melongena and S. torvum. Plant Cell Rep. 18: 791-796.

Kashyap V, Kumar SV, Collonnier C, Fusari F, et al. (2002). Biotechnology of eggplant. Sci. Hort. 97: 1-25.

Katznelson J (1971). Semi-natural interspecific hybridization in plants. Euphytica 20: 266-269.

Kaushal P, Malaviya DR, Roy AK, Kumar B, et al. (2005). Trifolium alexandrinum x T. resupinatum - interspecific hybrids developed through embryo rescue. Plant Cell Tissue Organ Cult. 83: 137-144.

Kowalczyk K, Kobryń J and Zieliński W (2008). Evaluation of pollen fertility in pepino (Solanum muricatum Ait.). Folia Hort. 20: 43-59.

Kumar AO, Panda RC and Raja RKG (1987). Cytogenetic studies of the $\mathrm{F}_{1}$ hybrids of Capsicum annuum with C. chinense and C. baccatum. Theor. Appl. Genet. 74: 242-246.

Mariana CPT and Alejandro SE (2006). Construction of a molecular identification profile of new varieties of Nierembergia linariaefolia by anchored microsatellites. J. Biotechnol. 9: 248-252.

Martins M, Tenreiro R and Oliveira MM (2003). Genetic relatedness of Portuguese almond cultivars assessed by RAPD and ISSR markers. Plant Cell Rep. 22: 71-78.

Monteiro CES, Pereira TNS and Campos KP (2011). Reproductive characterization of interspecific hybrids among Capsicum species. Crop Breed. Appl. Biotechnol. 11: 241-249.

Murashige T and Skoog F (1962). A revised medium for rapid growth and bio assays with tobacco tissue cultures. Physiol. Plant 15: 473-497.

Peregrine WTH and Ahmad K (1982). Grafting - a simple technique for overcoming bacterial wilt in tomato. Trop. Pest Manag. 28: 71-76.

Pickersgill B (1997). Genetic resources and breeding of Capsicum spp. Euphytica 96: 129-133.

Raina SN, Rani V, Kojima T, Ogihara Y, et al. (2001). RAPD and ISSR fingerprints as useful genetic markers for analysis of genetic diversity, varietals identification, and phylogenetic relationships in peanut (Arachis hypogaea) cultivars and wild species. Genome 44: 763-772.

Segeren MI, Sondahl MR, Siqueira WJ, Medina Filho HP, et al. (1993). Tomato breeding: 1. Embryo rescue of intersecific hybrids between Lycopersicon esculentum Mill. and L. peruvianum (L.) Mill. Rev. Brasil Genet. 16: 367-380.

Singh AK, Singh M, Singh AK, Singh R, et al. (2006). Genetic diversity within the genus Solanum (Solanaceae) as revealed by RAPD markers. Curr. Sci. 90: 711-716.

Singh PK and Gopalakrishnan TR (1997). Grafting for wilt resistance and productivity in brinjal (Solanum melongena L.). Hort. J. 10: 57-64.

Tikunov YM, Khrustaleva LI and Karlov GI (2003). Application of ISSR markers in the genus Lycopersicon. Euphytica 131: 71-80.

Wei YC (2010). Interspecific Hybridization Between Eggplant (Solanum melongena L.) and the Related Wild Species Solanum torvum SW. Master's thesis, National Pingtung University of Science and Technology, Taiwan.

Winnepenninckx B, Backeljau T and De Wachter R (1993). Extraction of high molecular weight DNA from molluscs. Trends Genet. 9: 407.

Yonemoto Y, Chowdhury AK, Kato H and Macha MM (2006). Cultivars identification and their genetic relationships in Dimocarpus longan subspecies based on RAPD markers. Sci. Hort. 109: 147-152. 